\title{
3 Okun Radio Online as an impetus for maintaining the dialects and cultural heritage of Okun-Yoruba people
}

\author{
Josephine Olufunmilayo Alexander
}

\section{Introduction and background}

The world's linguistic diversity is threatened by globalisation in which English and other international languages, such as French, Portuguese, Spanish and Chinese, have become dominant in education, commerce, law, international trade, politics, science, technology and economics. The global use of English, alongside the endorsement and promotion of national languages as part of a language shift to more functional and prestigious global languages, has resulted in the marginalisation of minority and indigenous languages. The linguistic landscape is further impacted in multilingual countries where standardised national languages have been imposed on minority and indigenous languages in addition to the superimposition of English as the official language of government and of instruction in education. The globalisation of the English language and the predominant usage of national languages have resulted in the death and endangerment of minority and indigenous languages.

Very little attention was paid to the loss and endangerment of the world minority and indigenous languages until Krauss' (1992) "plausible calculation" that " $90 \%$ of mankind's languages" stand in danger of going into extinction or being endangered in the twenty-first century. ${ }^{1} \mathrm{He}$ called out to world linguists to confront and stem this alarming development with the same kind of aggression with which the threat to biodiversity is being addressed. His call brought about increased awareness about the state of world languages, leading to major research and many publications on language shift, loss, endangerment, death and maintenance. These works and research were carried out by prominent linguists and sociolinguists (Fishman 1991, 2001; Fase et al. 1992; Ladefoged 1992; Grenoble and Whaley 1998a, 1998b, 2006; Crystal 2000; Bradley and Bradley 2002).

Between 6 and 9 June 1996, the UN, in collaboration with a number of its component organisations and other NGOs around the world, produced and signed the Universal Declaration of Linguistic Rights as a component of basic human rights. This emboldened speakers of minority languages all over the world. In addition, UNESCO prioritised works on endangered languages in addition to organising international conferences (Matsumura 1998). In 1993, it 
launched its "Endangered Language Project". It also provided support for a number of other projects and publications. There are numerous other NGOs around the world committed to the survival of indigenous languages (Foundation for Endangered Languages in the UK, the Society for the Study of Indigenous Languages of the Americas, the Gesellschaft für bedrohte Sprachen of Germany and the Australian Institute of Aboriginal and Islander Studies). Apart from linguists and sociolinguists, interest in saving and preserving indigenous languages has been promoted by anthropologists, missionaries, policy-makers, language planners, educators, media practitioners, humanitarian workers, students and visionary community leaders.

Batibo (2005) highlighted the multi- and pluri-lingual nature of African societies brought about by complex linguistic situations that allow for multiple choices and usage. This linguistic scenario sees some languages privileged by virtue of the political and socio-economic status vested in them. Marginalised languages with little or no value politically, socially and economically are therefore prone to gradual attrition and endangerment. Speakers of such languages are also disadvantaged as they continually shift from their own languages to the official and more prestigious ones. According to Batibo (2005: 93), the common cause of language shift and death in Africa "is the pressure that the weaker languages experience from more powerful or prestigious languages". He attributed the pressure to "demographic superiority, socio-economic attractions, political dominance or cultural forces". The sociolinguistic ecosystem of each African country is further described by Batibo (2005: 16) as unique, depending on its history and pattern of language use.

The general pattern of language use in Nigeria is trifocal, as in most African countries. This means that three languages are spoken and used by the same community distinctly and complementarily depending on the context and the status accorded to each of the languages. In the Nigerian multilingual milieu, the first of the three languages is English. It is the former colonial language and the official language adopted at independence. It is used in the domains of education as the language of instruction, government, business, diplomacy, the judiciary, international relations, trade, commerce, science and technology. It is also used as a lingua franca among Nigerians with different indigenous and regional languages. It enjoys global currency and status. It is therefore dominant, prestigious and regarded as the $\mathrm{H}$ (high) code in terms of its relationship with other languages.

Occupying second place in the three-tier structure of the pattern of language use and dominance are Hausa in the north, Ibo in the east and Yoruba in the south west. They are standardised and used as a lingua franca for inter-ethnic communication. They are also socio-economically prestigious but not at the same level as English. They are demographically superior and can be used together with English in certain official situations, such as early childhood education, lower primary school, mass media, local government and in some legislative and judicial sectors. There are further dialects subsumed under each language. These languages therefore attract second language learners from 
speakers of these dialects for reasons of wider communication, demographic superiority and socio-economic gain. In relation to the functions of the English language they will be referred to as L (low) code but in relation to their dialectal variations they are $\mathrm{H}$ code.

In the third position are dialectical variations of the three regional languages as well as many other ethnic indigenous languages, many of which are only spoken and with no standardised orthographies, appropriate grammar or dictionaries. Batibo (2005: 53) estimated these languages as constituting over 80 per cent of languages in Nigeria. They function mostly in the family and ethnic domain and are used as cultural media. They are referred to as minority languages. The speakers of any one of these languages are few compared to the speakers of English or the dominant regional languages, and their pattern of usage is restricted to their ethnic environment. Some of them are used as a language of intra-ethnic communication but with no conspicuous public, regional or national role. They also do not attract second language learners as they have no prestige because of their very limited and inferior socio-economic status. Speakers of these languages are forced to shift from their languages to the dominant regional languages and English because of a demographic inferiority and apparent lack of public and socio-economic function. They are therefore neglected, excluded and marginalised as a result of the complex dominant pattern of usage in the Nigerian eco-linguistic environment.

The environment is further complicated by the use of Pidgin English nationally as the language of the market place and of interpersonal relationships and inter-ethnic communication. Speakers of minority languages often feel psychologically inferior to those of the dominant languages, thereby developing a negative attitude towards their languages. They are often in a hurry to abandon both their language and their culture and sometimes their self-identity because of low self-esteem (Batibo 2005: 54). Another feature characteristic of minority languages is that their speakers encourage their children to acquire and learn the more dominant languages because of the opportunities they provide economically, socially and educationally. As a result, there is gradual attrition of such languages from generation to generation because of language shift. These languages are prone to endangerment if nothing is done to preserve and maintain them.

The Okun dialects (Owé, İjùmú, İyàgbà, Gbede and Bùnú) of Standard Yoruba are spoken by the autochthonous population of Okun people of Kogi State of Nigeria. The word "Okun" is a greeting which immediately distinguishes Okun people from other Yoruba ethnic groups. Both the people and their dialects are referred to as Okun. Other people within Kogi State who speak the Okun dialect are the Ọwọrọs and Igoin. A small number of Okun speakers are also found in Ekiti, Ondo and Kwara States of Nigeria. The dialects are mutually intelligible but are less comprehensible to other Yoruba ethnic groups and to those who speak Standard Yoruba.

Within the multilingual environment of Nigeria, Okun dialects are marginalised. They fall into the third place in the three-tier structure of pattern of language usage. As minority languages, they are in contact with other dialects of 
Yoruba, ${ }^{2}$ Standard Yoruba and English as well as Pidgin English. This means that Yoruba, Pidgin and English are superimposed on them. They are therefore regionally and nationally marginalised and devoid of any political, social, educational or economic value. Like all speakers of minority languages, the Okun people have been forced to abandon their dialect and to shift to another language with greater status and prestige: Yoruba, Pidgin or English. As highly educated people, many middle and old aged Okuns have moved to cities within Nigeria, while some have emigrated to Europe, Canada and the United States of America. These movements have further impoverished Okun dialects as the children of these Okun people are far removed from the traditional settings in which Okun dialects are actively used. The Okun dialects have therefore suffered gradual attrition, with low intergenerational transmission among those who live in the diaspora and in other cities in Nigeria. Okun dialects will continue to be prone to endangerment if nothing is done to reclaim, preserve, document and maintain them.

\section{Literature review}

The potential role that access to the internet could play in promoting effective language maintenance for minority and endangered languages was cautiously expressed, but with confidence and hope, by Crystal (2000), Buszard-Welcher (2001) and Hinton and Hale (2001). Their guarded optimism has since become a reality with the rapid development in technology and computer-mediated communication. The Web 2.0 revolution with a focus on social networking and multimodal sharing of information has widened the domain and functional choice of dominant standard languages. It has also significantly opened up a plethora of opportunities for the accessibility and visibility of minority languages, as evident from numerous Facebook sites and fora dedicated to indigenous languages which are marginalised or in peril of being endangered. For example, Buszard-Welcher (2001) analysed 50 websites on endangered languages and arrived at the conclusion that the internet has been instrumental in creating online communities that allow for the active usage of endangered or indigenous languages. This active usage, according to Buszard-Welcher (2001), brings about the establishment of new domains and modes of communication and in some instances written varieties of languages which were previously only spoken.

In her 2017 publication, Gertrud Reershemius cited seminal research and case studies to enumerate the advantages of using the internet to promote indigenous languages. Some of the works she cited include Mensching (2000), Ouakrime (2001), Warschauer et al. (2002), Karim (2003), Eisenlohr (2004), Cunliffe and Harries (2005), Androutsopoulos (2006), Deuber and Hinrichs (2007), Rajah-Carrim (2009), Reershemius (2010), Leggio (2011), Oiarzabal (2012) and Jones et al. (2013). The advantages emanating from the cited studies are highlighted as follows:

- the freedom that indigenous language speakers now have to initiate and develop what Reershemius (2016: 3) calls "their own mediatised spaces where they can assume a far more active role than previously the case"; 
- the provision of modern avenues for intergenerational transmission. Older speakers are much more aware of the need to preserve their indigenous languages (IL) while younger ones are more easily convinced, interested and persuaded to acquire and maintain them;

- the promotion of sound methodologies for archiving language data, inventing teaching and learning materials and providing support for standardisation processes;

- the creation of online communities to leverage the distance between indigenous language speakers who live in different parts of the world;

- the advancement of communicative practices that allow bottom up initiatives which accommodate individual as well as multiple content, authorship and participation.

New technologies and social media have also become prominent tools for research in sociolinguistics, especially in multilingual and multicultural studies (Harrison and Thomas 2009; Al-Saleem 2011; Sharma 2012; Kimmons 2014; Zhuravleva et al. 2016). Reershemius (2017: 35) attributed this development to two recent approaches in sociolinguistic research. The first of the two approaches is "mediatisation". According to her, mediatisation is: "how the communicative practices of individual speakers as agents of change may model the way they use language on the media and how this in turn shapes the way communication is carried in various different media". The approach is associated with the works of sociolinguists such as Krotz (2003, 2007, 2009), Coupland (2014), Hepp (2014) and Androutsopoulos (2014). She identifies the second approach as the upsurge in computer-mediated communication with its interactive technologies, "Web 2.0".

Small and marginalised communities have taken the advantages that new technologies provide on the web to promote not just their indigenous languages but also their identity as well as their cultural and traditional heritage (TiamTong 1996; Warschauer 1998, 2000; Sallabank 2010; Seargeant et al. 2012; Campbell and Huck 2013; Joubert and Biernacka 2015; Ola-Busari 2015; Stern 2017). The Okuns, like all other indigenous people all over the world, have taken up the opportunities provided by the Web 2.0 revolution to advance their ethnic interest. They have found ways to reinvent themselves and to develop social cohesion, wherever they are in the world. Among such efforts are the Okun Community on Facebook, with 30,787 members, Okun Summit with 13,501, Okun Professional Network with 357 and Owé Forum with 10,866. Okun people are also intellectualising Okun knowledge, culture and traditions through OmoOkun (2014), an interdisciplinary journal on Okun-Yoruba, and a book on "Okun-Yoruba proverbs, idioms, wise sayings and some aspects of culture" (Samuel 2013). In addition, there is now the Okun Development Union to advance the cultural, political, economic and social well-being of Okun people. Apart from these collective efforts, individuals within the Okun community are promoting Okun dialects through music and art. One of these initiatives is Okun Radio Online. 
Okun Radio Online was founded in 2013 by Lanre Ejibunu, now living in Houston Texas, where the radio is located. The website (http://tunein.com/ station/?StationId=214169) summarises the founder's vision in the following words:

Okun radio is the first Okun broadcasting service in the community. We need a voice. Our resolution is to promote the culture, music, food, tradition and heritage of Okun land in diaspora. We therefore take pride in offering the best in broadcast. We are dedicated to serving the needs of our customers each and every day. With many professionals ready for the promotion of Okun land through this media, you are in for the best.

The radio is a $24 / 7$ free internet radio transmission described by the founder as "the voice of the Okun-Yoruba", connecting Okun people around the world with those in Okun land. It promotes culture and heritage through language and music, recognising that most Okun people in the diaspora, especially the young, have limited knowledge of their culture and heritage. Okun Radio "is committed to providing the best in Okun music" with the mission "to spread positive musical vibes, love and unity across the people of Okun land in the diaspora" (www.okunradio.online). It had 2,400 followers on 17 June 2017 (http://tunein. $\mathrm{com} /$ station/?StationId=214169) and can also be accessed via Tunein, Facebook, Twitter, Google Plus, Linkedin, Instagram, YouTube and SoundCloud.

The founding of Okun Radio Online resonates with what other ethnic, indigenous and linguistic communities around the world are doing to leverage the difficulty of not being able to set up their own media outlets as a result of their minority status. According to Uribe-Jongbloed (2016: 615) "ethnic and indigenous minority media outlets have appeared all over the world as a result of lower technology costs, increases in networking, and more pressure upon majorities to support minority interests (Alia 2010; Browne 2005; Roth 2000)". UribeJongbloed further asserts that the worldwide appearance and growth of ethnic, indigenous and linguistic minority media "has attracted particular attention to these forms of media production, prompting academic interest in representation and cultural preservation - including language maintenance".

This chapter is an exploration of Okun Radio Online. The focus is on the radio programmes and the interviews conducted on the programmes. The overarching question is whether the radio has the potential for promoting Okun dialects and the traditional and cultural heritage of Okun people. Two specific questions are addressed:

1 How are Okun dialects maintained on Okun Radio?

2 How do the programmes on Okun Radio promote the traditional and cultural heritage of Okun people at home and in the diaspora? 


\section{Theoretical framework}

Language and ethnicity are closely linked, especially in a multilingual country such as Nigeria where there is a strong correspondence between language group and ethnic entity. The relationship also explains why language marginalisation is predominantly characteristic of ethnic minorities. The correlation between the two informs the choice of primordial theory of ethnic studies alongside Paulston's social mobilisation theory of language maintenance as frameworks for this study.

Primordialism, according to Siziba and Wood (2015: S36), “defines ethnicity as premodial". This means that ethnicity, in the words of Wolff (2006: 33), is "deeply ingrained in human history and experience". The theory reflects the identity of the Okuns as an ethnic group. Historically from Ile-Ife, the earliest of Yoruba Kingdoms, the Okuns as ancient people migrated as a result of geographical dispersion to occupy more lands. They now constitute the KabbaBùnú, the İjùmú, East Yagba, Mopa-Muro and the West İyàgbà Local Government Areas of Kogi State; an area previously referred to as Kabba Division of Kabba Province. Present-day Okun land, according to Samuel (2013: vii), "covers an area of approximately 7,270 square kilometres with a population of about 3 to 5 million". In terms of location, it has Kwara State as a boundary to the north and west, Okehi and Lokoja Local Government Areas of Kogi State to the east and Edo and Ekiti States to the south. The Okuns share a common ancestral heritage and traditional culture, such as the social system of age grade, chieftaincy titles and ancestral worship of Egungun, Ebora, Ohoin, Ogun, Orisa and a number of male and female cults. Like all Yorubas, they have a very rich cultural heritage and strong values but their unique variants of Yoruba and their peculiar onomastic practices set them apart from other Yoruba ethnic groups.

The ethnic description of Okun people above resonates with Bayar's (2009: 1641) definition of ethnicity in relation to primordialism as "an ascriptive identity that is primarily based on assumed kinship with a combination of race (i.e. phenotypical traits such as skin colour), language, religion, geography and culture". In addition, Bayar (ibid.) states that primordialism assumes ethnic identity is fixed once it is constructed. This is apparent in the shared Okun cultural belief system, territorial location and through their origination from Ile Ife. ${ }^{3}$ Siziba and Wood (2015: S37) present the three basic arguments at the core of primordialism as follows:

- Ethnicity is an ascribed identity or assigned status which is inherited from one's ancestors.

- Ethnicity is static; ethnic boundaries which demarcate who is a member of the group and who is not are fixed or immutable.

- Common ancestry determines ethnicity.

The main tenet of primordialists according to Yang (2000: 42) is the primordial bonds that give rise to and sustain ethnicity. Based on these arguments, we can 
describe the ethnicity of Okun people as ascribed, fixed and rooted in their unquestionable shared ancestry. Contrary to the primordialists, social constructivists argue that ethnicity is not primordial, in spite of the common acknowledgement that members of an ethnic group may experience it primordially. Constructivists base their argument on the recognition that the conception of ethnicity has potential for change depending on the purpose for which it is used, as well as new opportunities that may be opened over time. For instance, ethnic conflicts may arise over a contention for material resources and from real or perceived deprivation. In the same vein, ethnic solidarity may stem from a strong desire and will to reverse linguistic, political, socio-economic and cultural marginalisation brought about by the minority status of ethnic groups. Either scenario presents the possibility of ethnic mobilisation (McKay 1992; Horowitz 2002). A more rounded conception of ethnic identity based on Wolff's (2006: 36-37) definition below is adopted for our purpose in this chapter. According to Wolff:

ethnic identity should perhaps be seen as something that has roots in a group culture, and historical experiences and traditions, but that is also dependent upon contemporary opportunities that can be a useful instrument for mobilizing people for social, political, or economic purposes that may or may not be related directly to their ethnic origins.

The adoption of the broader view of ethnicity brings us to Paulston's social mobilisation theory of language maintenance. According to Paulston (1994: x), the theoretical model is grounded on a wide variety of data. She enumerated the data as consisting of her own

fieldwork data and school visits on five continents, her living in Morocco, India, Peru, Sweden and Spain, teaching courses on language planning and directing dissertations on language shift and spread, as well as the examination of numerous case studies of social, political, and religious groups in multilingual situations.

The theory also perceives language as a social resource available to ethnic groups for language maintenance (Paulston 1994: 21-22). The core of the theory lies in Paulston's suggestion of four types of social mobilisation in a continuum relationship rather than as four separate kinds (Paulston 1994: 29). The four types of social mobilisation are:

- ethnicity which corresponds to the notion of old ethnicity;

- ethnic movement which is based on the concept of new ethnicity;

- ethnic nationalism;

- geographical nationalism.

We are concerned in this study with the first and second types of social mobilisation. 


\section{Josephine Olufunmilayo Alexander}

As mentioned earlier, the marginalisation of an ethnic minority translates to the marginalisation of their languages as minority languages. Such languages as explained in the introduction are confined to third place in the three-tier structure of language usage. Dominated by English, Pidgin and Standard Yoruba, the Okun dialects are in peril of endangerment. The fear of losing their language and consequently their identity and cultural heritage has awakened the sense of ethnic solidarity among Okun people. In pursuit of their ethnic interest, they have employed their ethnicity as a resource for mobilisation. According to Wolff (2006: 33), ethnicity is "foremost a resource in the hands of leaders to mobilise followers in the pursuit of other interests" other than primordial identity.

Commenting on the usage of the word ethnicity in relation to language shift and maintenance, Glazer and Moynihan (1975: 5) underscore the perils of minority languages in the following suggestion:

The new word is "ethnicity" and the new usage is the steady expansion of the term "ethnic group" from minority and marginal subgroups at the edge of society - groups expected to assimilate, to disappear, to continue as survivals, exotic or troublesome - to major elements of a society.

Related to the above suggestion is the perception that ethnicity is a problem that must be overcome in nation building and language planning in order to foster national unity. Ethnic groups are, for example, seen as "vestiges of a primitive past that are destined to disappear" (Elazar and Friedman 1976: 4).

There has been a revival of ethnic awareness and affirmation that renders the above sentiments obsolete. The shift in the perception of ethnicity is articulated in the work of Bennett (1975b). The old view of ethnicity as shared language, culture and belief as well as mobilisation around cultural symbols (Bennett 1975b: 4; Paulston 1977: 181) constitutes the first type of social mobilisation. This notion of ethnicity has, however, given way to a new perspective of ethnicity described by Bennett (ibid.) as "a set of strategies for acquiring the resources one needs to survive and to consume at the desired level". Above all, Bennett states that the new ethnicity differs from the old notion of ethnicity in that it is "cognitive ethnicity, a self-chosen ethnicity" (1975a: 9). This new view of ethnicity equates to Paulston's second type of social mobilisation.

The new ethnicity has been further enhanced, as demonstrated in the literature review, by the Web 2.0 revolution, new technologies and the advent of interactive social media. This development has further energised and invigorated ethnic minorities to find novel and innovative strategies for preserving, restoring and documenting their marginalised language and culture. Evidence for this comes in the form of the numerous studies which have been cited, bringing new approaches to sociolinguistic research because of the new opportunities provided by the Web 2.0 revolution. 


\section{Data and methodology}

In conducting this research, I accessed, observed and listened to the weekend programmes on Okun Radio Online for four months between February and May 2017. During this period, I employed an online ethnography methodology to collect data. The term online ethnography, according to Skågeby (2011) "envelopes document collection, online observation and online interviews". In the four months that I visited the radio site regularly, I explored the written content and purposely made field notes on the vision of the founder and the content of the advertised programmes. The major data collected in these four months were the content of indigenous music and interviews aired on the radio. I selectively listened and transcribed the content into English, converting oral presentations to written texts for the purpose of content analysis. Listening repeatedly to the programmes also afforded me the opportunity to closely observe the use of the different Okun dialects as well as the promotion of Okun cultural heritage. During close observation, I intuitively probed the underlying meaning, message and purpose embedded in the songs. On one Saturday I called in to participate in the programme online. This gave me the opportunity to establish contact with the founder. As a participant observer on that day, I was able to interact with the guest speaker on the programme. I also had a first-hand experience of how the radio operates and how it is able to connect with Okun people within and outside of Nigeria.

After four months of listening, I booked an appointment to interview the founder. The interview was unstructured and was conducted online via WhatsApp on 20 May 2017. The outcome provided additional information on the radio, especially on the programmes that have been aired before but are no longer running and are documented on YouTube, iTunes and SoundCloud or in the possession of the presenters. Apart from being able to question the founder on whether he was achieving the purpose for which the radio was established, I was also connected to the people who presented the different programmes, paving the way for contacting and arranging further unstructured interviews with them. Five of such interviews were conducted online via Messenger or WhatsApp on 17 June, 13 July, 15 July and the other two on 29 July. Three regular listeners identified online via social networks were also contacted to give their perspective on the performance of the radio. Their responses were elicited through very short interviews conducted on 29 and 30 July via Facebook Messenger.

As a qualitative approach to data collection in virtual communities, online ethnography allows researchers to probe and interrogate "the deeper reasons for behaviours or sentiments" (Skågeby 2011). This methodology provides an effective tool to carry out online content analysis of the radio programmes alongside the interviews conducted. It allows researchers to describe and make inferences about online material through systematic coding and interpretation. The data collected were qualitatively analysed using a thematic approach to content analysis.

There were no real ethical dilemmas as the people interviewed (except one) were adult Okun indigenes aware of the common effort of preserving, documenting 


\section{Josephine Olufunmilayo Alexander}

and maintaining Okun dialects. The names of the founder, presenters and audience were also directly mentioned or referred to. There is no harm or threat in doing so as Okun Radio Online is open and free and participants are always asked to introduce themselves on air.

\section{Data analysis and discussion}

The unit of analysis is the programmes aired on the radio and the interviews granted by the presenters of the programmes. The analysis also benefits from the written information on the home page of the radio online as well as the field notes recorded during close observations, while listening to the programmes and being a participant observer.

\section{The weekend programmes}

These programmes are aired on Saturdays and Sundays but mostly Saturdays. They are the most visible programmes scheduled on the radio website and the ones that are available online. The programmes are presented by Mr Lanre Ejibunu, the founder. Typical Saturday programmes are scheduled as follows:

\section{Shows}

Saturday Morning Show

Okun Show

Saturday Show

Saturday Evening Show

Saturday Night Show
Time

6a.m.-10a.m.

10 a.m. -2 p.m.

2 p.m. -6 p.m.

6 p.m. -10 p.m.

10 p.m.-2 a.m.
1

2

3

4

5

6

7

8

9

10

11

12

13

14

15

16

17

18

19

20

21

22

23

24

25

26

27

28

29

Eto alarinrin! A programme of excitement! 
In this jingle, the presenter deliberately and intentionally invites listeners in Nigeria and in the diaspora to tune in and take advantage of enjoying the entertainment and pleasure that the programmes provide in their own dialects. Okun people living abroad will find this invitation particularly exciting and significant as some of them may be living in countries where they have no opportunities to communicate and interact with anyone in their dialects. For this author, for example, it was so fascinating to listen to Owé dialects online and to enjoy the creativity of the artists who have composed their songs using various Okun dialects. But even more significantly, listening to and transcribing the songs into texts in English revealed how much Okun vocabulary I have lost, while it was even more alarming to realise the difficulty I had remembering the meanings of words and interpreting them accurately and appropriately. This confirms the gradual attrition of Okun dialects and the need to document, preserve and maintain them for intergenerational transmission.

Another jingle used to rally Okun people at home and abroad and to embrace their dialects, and by extension their ethnic identity and cultural heritage, is the one below in English and Owé dialect:

Okun Radio! Connecting Okun people all over the world!

No matter where you are, this is your radio. It is yours, it is our own.

Asa, Ise, ati ede gha. Culture, tradition and our language.

Radio Okun, Okun Radio. Tell others about it.

This jingle speaks directly to the fundamental objective of the founder as stated on the radio website and quoted earlier in the literature review as follows:

Okun Radio online is the voice of the Okun-Yoruba, connecting Okun people around the world with those in Okun land. It promotes culture and heritage through language and music recognising that most Okun people in the diaspora, especially the young, have limited knowledge of their culture and heritage.

The jingle also accentuates the founder's vision, as highlighted in the literature review section. Again, we see a deliberate attempt on the part of the founder to mobilise his ethnic group socially for the purpose of affirming their identity and their common linguistic and cultural interests.

Within our theoretical framework of ethnicity and social mobilisation, $\mathrm{Mr}$ Ejibunu qualifies to be described as a leader of his ethnic group. He explores the ancestral affinity of his people as well as his professional competence as a broadcaster $^{4}$ to promote and fulfil his vision as an agent of change in his community. His action also extends the numerous publications that have demonstrated how minority ethnic groups are tapping into the opportunities provided by new technologies to leverage their invisible status through the creation of their own media outlets.

The content of the weekend programmes is characterised by the commitment to use Okun Radio as an avenue "to providing the best in Okun music" with the 


\section{Josephine Olufunmilayo Alexander}

mission "to spread positive musical vibes, love and unity across the people of Okun land in the diaspora" (www.okunradio.online). In the following subsections, we analyse and discuss the music played on the programmes as well as three other important events that take place while the programmes are broadcast.

\section{Music}

About 90 per cent of the music played is in Okun dialects of Owé, Ìyàgbà, İjùmú, Bùnú and Ọwọọ. The following jingle from the radio confirms the predominance of music on the radio:

We make, produce, promote and play music, music is our life. Okun is our passion.

Call 6054751681 to hear Okun Radio live!

The primary aim of the music is to entertain but the analysis of the content of the songs reveals three main features. The first relates to songs that are spiritual in nature. These songs exalt God, offering praise and thanksgiving for His benevolent blessings. Let us look closely at one of such songs:

Seun! Seun je

Olorun mi mi me wa wo

Tori ore jije

Tori Ore mimu

Tori Alafia

Tori aya ati Omo

Igbe ga alibi ise

Abo irin ajo

Olorun mi mi me wa wo seun seun

Olorun ghon dami

Atobajaiye

Olore Ofe

Alagbara! Olugbala!

Oba Giga!

Baba Mimo!

Olorun Alpha ati Omega

Wo se ore

Me wo gbagbe

Were, were, ku we ko mi yo

Wo sore me wo gba gbe
Thank you! Thank you indeed

My God I am greeting you

For the blessing of food

For the blessing of something to drink

For peace of mind and body

For wife and children

For promotion in the workplace

For safety return from travel

My God I greet you, thank you!

Thank you!

The God that created me

The one that is sufficient to live

life with

The owner of abundant blessing that is free

The owner of power! The one that

saves!

Great God!

Holy Father!

The God that is the beginning and the end

Thank you for your blessing

I cannot forget

Quietly, quietly, you deliver me

You bless me, I cannot forget 
In this song, the composer is thanking God directly for himself and by extension for those listening to him for the provision of food and drink, peace of mind and body, wife and children. The thanksgiving also extends to other areas of life, such as promotion at work and safety on the road. After thanking God for specific blessings, there is an acknowledgement of God's benevolent attribute as a Father who is sufficient, who blesses abundantly, freely and quietly. God is extolled as "the beginning and the end", the all-powerful, "Great God", "Holy Father" whose blessings one cannot forget. It also exhibits the faith and trust that the people have in God to provide for their daily necessities, such as food and safety.

Songs in this category also carry some air of evangelisation. A deeper reflection on the spiritual songs reveals their therapeutic and emotional purposes. This is particularly so for those in the diaspora who live far away from home and sometimes under the harsh reality of being strangers in their countries of abode. In some instances, people may be undocumented in those countries, finding it difficult to be legitimately employed while waiting to legalise their residency. People living outside their home country and far away from others who share their ethnic affinity are also under pressure to show that they have attained material wealth when in fact many struggle to make ends meet. It is also natural for people in the diaspora to miss their family and homeland. The spiritual songs therefore serve as therapy in those stressful situations as they uplift their spirit and offer emotional and psychological support to prepare them to face each day. The following song is a typical example:

Ro ojo re laiye mi
Nde mora
Baba mi mi reti re
Lano eti okun wo ran omo Isreali lowo
Ire mi ya tun nipe ghun to de
E mere bami jijo
E mere bami yo
Ayo we ti reti
Ya ni tupe ghun to de
Anti, Boda mi
Everybody

Rain your rain in my life (Bless my life)

So I can experience relief My Father, I am waiting on you Yesterday, by the sea side you helped the children of Israel My blessings will not be long in coming They (people) will dance with me They (people) will rejoice with me The joy that I have been expecting Will not take long before it comes My sister, my brother Everybody

A close reading of the content of this song reveals an appeal to God to send forth His abundant blessings and to bring to fruition the hopes and aspirations that would bring relief and cause others to rejoice on one's behalf. It is a song that anticipates God's solution to problems. God is trusted to meet expectations by analogy to how God parted the sea for the Israelites to deliver them from Pharaoh. We also see here the use of rain to symbolise blessing. The element of 
anticipation is seen in the choice of words such as "waiting" and in sentences such as "My blessings will not be long in coming", "The joy that I have been expecting will not take long before it comes". There is also the interjection of the English word "everybody". This is used to rally everyone to believe in God's grace to meet their expectations as each one waits on Him.

Sometimes the songs are in recognition of what the Lord has accomplished in people's lives, especially when they have become successful after a rough start to life abroad, as insinuated in the song below:

Mo ranti Eleda mi ooo

Ibi wo ti mu mi jade

Se oni ki araiye ri, Ya ho no mo

Oni bam o mo ughun e pe wonder,

Me me wo ba wo pin ogo re Baba

Iyanu nise Baba

Iyanu nise Omo

Iyanu nise Emi mimo

Ayin o logo

Okuta Sioni

Iyin re ke larun mi Jesu

Olorun layin mi

Me me tobe Oba mimo

Gbogbo Ogo je tire
I remember my Creator

Where you brought me from

It is today that the people of the world foundation can see, no-one knows my foundation

One who does not know what miracle

is or what is called wonder

I cannot share in your glory

Wonder is the work of the Father

Wonder is the work of the Son

Wonder is the work of the Holy Spirit

We praise you

The rock of Sione

Your praise is in my mouth Jesus

God is behind me

I am not worthy Holy God

All praise be unto you
1

2

3

4

5

6

7

8

9

10

11

12

13

14

15

16

17

18

19

20

21

22

23

24

25

26

27

28

29

30

31

32

33

34

35

36

37

38

39

40

41

42

43

44 
E ja parapo, ani fe ara gha

A jen je se

Ekun ya ho no mola Eje ka fife bara gha se oo Okun Unity
Let us come together in unity and harmony

In order to achieve progress and success I greet you, no one knows tomorrow Let us interact in love oo No compromise!

In this song, there is a direct appeal to all Okun people to bury their differences and unite in love in order to succeed and make progress. The singer calls out the different groups - İjùmú! İyàgbà! Bùnú! Ọwọrọ! Owé! - and urges them all to come together in unison. The urgent need to interact in love is supported by the biblical tenet that love is the overarching principle of the Ten Commandments in the sentence "Ife la koja ofin o", meaning "love is the ultimate goal of all commandments". The urgency is further encouraged by the fact that there is no need to delay as "no one knows tomorrow".

The Okun people are also challenged in terms of forging unity among themselves, as each member of the ethnic group often tries to root for their own instead of coming together as a people with the same identity, common dreams and purpose. As a result of the tension and complexities that arise from such conflict, Okun people have found themselves marginalised politically and economically within Kogi State and at the national level in the country. In this song, the artist reminded his listener how long he has been singing about the importance of unity rather than discord and segregation among Okun people. He appeals for everyone to cooperate to uplift Okun land and to work for its progress irrespective of how small or large the groups who make up Okun land are. Specifically, the singer calls out the different groups so that none of them would feel excluded from this call to unity, as can be seen from the following extract:

\section{Omo Kabba}

Isanlu, Iyara, Indigene of Ole and Ife

Omo Iyamoye, Okedayo and Aiyegunle

Omo Okun o

Ogidi, Mopa, Aiyetoro, Ogale

Iyah Gbedde, Ohakiti and Odo Ape

Ikan soso ka se, Omo Okun
Indigene of Kabba

Isanlu, Iyara, Indigene of Ole, Ife

Indigene of Iyamoye, Okedayo

and Aiyegunle

Indigenes of Okun o

Ogidi, Mopa, Aiyetoro, Ogale

Iyah Gbedde, Ohakiti and

Odo Ape

We are one, Okun Indigene

The call for unity is further promoted in the rest of the song by the need to forgive and reconcile so that other ethnic groups within Kogi State can see that the Okun people have achieved togetherness and cannot be marginalised or manipulated politically. The part of the song alluding to this inference is quoted below: 
Eje nye gbogbo oni United we stand

Let all people know with certainty

Omo Okun o Indigenes of Okun o

that united we stand

1

2

3

4

5

6

7

8

9

10

11

12

13

14

15

16

17

18

while other songs are used to encourage those in the diaspora to come home regularly and to contribute to the development of their community. An example of a song that indicts feigned behaviour is:

Ore mo ho oyinbo hi mi

Friend, don't speak English to me

I know you at home

You are the child of someone I know

I have not seen you for a while

I am an Okun indigene

These people speak their own

language

Let us speak our own language too

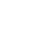

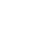
1

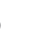
4 6 7

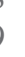

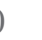
2 7

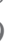
0

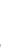
3 


\author{
Omo Okun kun mise \\ Omo Okun ku we se
}

\section{I am an indigene of Okun}

You are an indigene of Okun

This song speaks to Okun people who feign ignorance of their dialects and behave as if they are no longer part of their ethnic group abroad. The song appeals to such people to stop pretending and embrace their identity, just as the people whose language they are trying to shift to have embraced their own identity and language. The part of the song that highlights this fact is in bold.

The following exemplifies the songs that encourage Okun people in the diaspora to come home regularly and not forget their roots. The singer advocates for the need for Okun people to uplift their cultural heritage. The parts that accentuate these sentiments are in bold:

\begin{abstract}
Asi ki asi oo
Ile ki le oni

Ibi obi ni hi emeje ko

Ooo eje a ko

Ya ho ni mo nile

Ibi obi gha lokun

Ibe amo ti gha

Ajo ole dabi ile

Eja ranti ile oooo

Eje aparapo

Gbe asa gha laruge

Omo Okun to ti rinrin ajo

Ajo ole dun ka gbagbe ile
\end{abstract}

Being abroad is being abroad

Home is one's home

Where you are born cannot be renounced

Ooo let us go home

There is no one that does not have a home

Where we are born in Okun land

Is where we come from

Living abroad can never be compared

to home

Let us remember home oooo

Let us come together

To uplift our cultural heritage

People of Okun who have sojourned

abroad

Abroad cannot be so sweet to forget home

In addition to music in indigenous Okun dialects, popular Yoruba music from seasoned artists such as King Sunny Ade and Ebenezer Obey are sometimes aired, as well as Yoruba choruses. Okun Radio also showcases young Okun artists and has helped in popularising Okun music both at home and in the diaspora. Among such artists are Omo Ayo, who has become a popular hip hop artist within Nigeria, Gboyega Ipinmoroti, who weaves traditional oral tales and folksongs into his music, and Oluwatosin Jaja-Olorunmolu. These artists have also been Okun Radio guests and have had the opportunity to speak about their music.

\section{Interviews and guests}

This is one of the regular features of the weekend programmes. Prominent Okun community leaders, professionals, politicians and grassroots community people are interviewed. The interviews focus on pride in their motherland, achievements, professional success and contributions to community development. Interviews are 
conducted during the programmes or are pre-recorded and played on the programmes mainly by Mr Ejibunu or Hajia Rakiya Yusuf, who has volunteered to be the operational manager for the radio. In the interview with Mr Ejibunu, he recounted how at the inception of the radio, he interviewed all the traditional Kings of Okun land in order to seek their blessing, familiarise them with the objectives of Okun Radio and seek their support in mobilising Okun people to help make the radio a platform for cultural expression and a forum for community development. The interviews are archived on SoundCloud, YouTube and iTunes. Other prominent Okun community leaders that have been interviewed include the late Olori Maria Olobayo (wife of the late Obaro of Kabba), the president of Kabba Development Union, the local government chairperson and prominent grassroots men and women.

The interview sessions provide an opportunity for elected politicians to be held accountable. Okun representatives in the National Assembly, House of Representatives and Senate have all been interviewed and given a scorecard based on their performance. Prominent professionals in law, journalism, music, theatre and civil societies have also been interviewed to showcase the achievements of Okun indigenes and to encourage young people.

In addition to the interviews, a guest is occasionally invited to speak on current issues from Okun local government areas. Some of the issues that guests have addressed include the issue of an embattled Senate representative facing recall, the motivation for a Federal University of Agriculture in Kabba, the marginalisation of Okun people within Kogi State, elections, youth matters and developments in agriculture.

\section{Okun This Week}

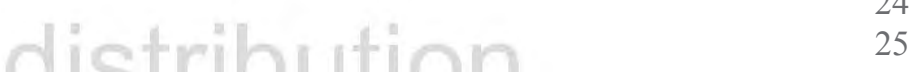

This is facilitated by Mr Korede Emmanuel, a native of Iyara (İjùmú) and a radio presenter on Kogi FM in Nigeria. Once a week, he compiles a summary of events from Okun land, including traditional festivals, political stories and news on personalities and institutions. He sends the broadcast via WhatsApp to Mr Ejibunu, who subsequently presents it on the weekend programme. One event reported by Hajia Rakiya Yusuf was the annual Ogidi Day Celebration in May 2017. The event includes free medical consultations and medication for the elderly, a mountain picnic, cultural performances, traditional food and delicacies and a youth concert. Other ceremonies promoted include Kabba Day in November, burial ceremonies and other Okun developments and events. The founder promised to cover Ogidi Day on Okun Radio for those who could not be physically present. In our interview, Mr Tunde Olugbami commended Okun Radio for promoting Ogidi Day, noting in particular the pictures of the event posted on Instagram.

\section{Other programmes}

In the course of the interview with Mr Ejibunu, I asked him when other programmes that are visibly advertised on the radio websites are broadcast. These 
programmes are "African Presents", "Daybreak Broadcast", "Gospel Rhythm", "Morning Devotion Show" and "Night Show". In his response, he explained that, even though the radio is conceived to operate 24 hours daily, the current schedule is focused mostly on weekends. He attributed the delay in operating fully to lack of money. According to him, "initiating and starting Okun Radio Online has been a very rough, tough and lonely journey". He struggled financially to keep the website operating, stating that few people had wanted to do anything for free. However, he joyfully told me about the voluntary contribution of five Okun people who on their own initiated programmes that have been broadcast on the radio. He gave me the title of the programmes as well as the initiators for me to contact and interview. The five programmes are "Iye Gha Ghon", "Owé on Radio", "Ufe Okun", "Ijomijo" and "Idi Aro". The programmes are analysed and discussed in the rest of this section.

\section{Iye Gha Ghon}

The title of this programme translates to "Our Olden Days Mother". The programme is initiated and produced by Hajia Rakiya Yusuf, the volunteer operational manager and an Owé indigene. In the interview with her via WhatsApp on 17 June 2017, I asked her to explain the idea behind this programme. She said her motivation came from the way present-day young girls from Okun land are becoming more wayward, getting pregnant early, having children with several men and not displaying the tolerance and endurance of older Okun mothers. In the programme, she promotes the various ways traditional Okun mothers cared for their husbands and managed their homes, and how modern working mothers juggle responsibilities for job and home as models that young girls should emulate and strive for. She does this either by telling the story of mothers who have displayed exemplary care, patience, tolerance and support for their families or by directly interviewing those she considers role models. Her most notable interview was with a woman who endured the hardship of a polygamous relationship, in which the senior wife reigned supreme. Another interview showed the virtue of an older woman who demonstrated the utmost care and love for her husband through a spirit of generosity, the use of cognomen and traditional Owé songs. She also interviewed the late Olori Maria Olabisi Olobayo, the wife of the late Obaro of Kabba, a modern woman who combined being a queen with being a secondary school principal and running a project for widows. The interviews were conducted in Okun dialects. The aim of the interviews, according to her, is to educate young girls and encourage them to change their behaviour. She also enjoyed the programme because it gave her the opportunity to interact and see the world from the perspectives of those she interviewed as well as giving her the opportunity to mentor young people. She lives in London but spends half of the year in Nigeria. 
Owé on Radio

This programme is the brainchild of Dr Bolanle Elisabeth Arokoyo of the Department of Linguistics and African Languages at the University of Ilorin. She is an Owé indigene who has written the books Owé Linguistics (Arokoyo 2013) and Owé Bilingual Dictionary (Arokoyo 2017). I chatted with her on Facebook Messenger and subsequently interviewed her on WhatsApp on 13 July 2017. I asked her about the idea behind this programme. According to her, she initiated the programme with the aim of teaching the Owé language in module form by exploring topics such as parts of speech, time of day, greetings, numerals, names and seasons. Her teaching is targeted at Owé people in the diaspora and by extension other Okun people whose versions of Okun dialects are mutually intelligible with Owé. In particular, the programme is created for the benefit of adults who left home many years ago and whose children were born abroad and who consequently have limited or no access to the language. Her overall purpose is to reaffirm Owé ethnic identity and Okun heritage.

She explained how the programme was produced. She recorded eight 20-30 minute episodes which she would then send to Mr Ejibunu to schedule. In the first episode that I listened to, the Owé language was identified as a dialect of Yoruba, the similarities and differences between the orthography of Owé and Standard Yoruba were explained. A brief history of how Owéland originated was also presented. Even though academic in nature and facilitated in English, the presenter started by greeting in Owé but code-switched to English. The programme highlighted the characteristic features of Owé, especially the role of tone in meaning making. For instance, words written or spelled the same way on the surface level have different meanings depending on the tonal mark on each of the letters. The letters of Owé include 19 consonants and 7 vowels. The difference between the consonants and those of Standard Yoruba is the presence of the voiced labio velar fricative $/ \mathrm{gh} /$ as well as the substitution of the vowel /i/ for /u/ as in:

Owé dialect
Eghin
Agha
Ule
Usu

Standard Yoruba
Eyin
Awon
Ile
Isu

There was a demonstration of how words are generally written as they are pronounced but with the unique feature of some consonants that are voiced but not written.

I asked her the challenges faced in preparing the episodes in Nigeria and sending it through to the USA. Her biggest challenge was with internet access, followed by the responsibility of keeping track of the dates the episodes would be broadcast and the lack of feedback on how the lessons were received by the listeners. In concluding the interview, I asked her about the prospect of the radio 
service. Like Mr Ejibunu, she identified finance as a threat but acknowledged that, in spite of this challenge, the radio has good prospects of continuing because internet access is generally easy for the targeted audience of Okun people in the diaspora, who also share news about the programmes on social networks such as Twitter, Facebook and WhatsApp.

\section{Ufe Okun}

"Ufe Okun" transliterates to Proverbs of Okun. It is initiated and produced by Mr Oke, an educationist who served as principal of several secondary schools in Kabba/Bùnú local government as well as different parts of Kogi State. He is well versed in the history and culture of Owé people and is the author of Owé T'ano: Oke Meta Owé Cultural Heritage (Oke 2016).

Ufe Okun brings into focus all the dialects of Okun people through proverbs (Ufe) for the benefit of all those at home and in the diaspora. In the interview I conducted with him via WhatsApp on 15 July 2017, he explains Ufe Okun as a programme that compares how common proverbs are verbalised in the different dialects of Okun land: Owé, İyàgbà, İjùmú and Abinu. His aim is to highlight the similarities and differences in the ways a proverb is said in order to explore the possibility of standardising Okun dialects based on the similarities. In each programme, Mr Oke would ask a representative from each of the four dialect groups to say the proverb in his or her dialect, after which he highlighted the differences, often in the use of vowels at the beginning of words. For example, instead of $/ \mathrm{u} /$ used by two of the dialects, the other two use /i/. Each representative is also called upon to say what the proverb means within their context and the situation in which it might be used. This is followed by discussion of how the proverb could be extended to wider Nigerian society, demonstrating its function and communicative usage. Occasionally, an analogy is drawn between the proverbs and other well-known English proverbs. All the dialects of Okun people are used on this programme. Like Mr Ejibunu, Hajiya Rakiyah Yusuf and Dr Bolanle Arokoyo, Mr Oke is an indigene of Owé.

\section{Ijomijo}

This is a programme initiated by Ms Esther Folashade Ajayi, although she refers to herself on the programme by her clan praise name "Iyemale", meaning "from the Omo Male Clan". The programme title, Ijomijo, transliterates to "The Days of Old". The programme is based on things that happened in the past but which are being erased by modernity or language loss. She indicated in the interview conducted with her on 29 July via WhatsApp that the programme is conceptualised to restore the cultural norms and practices that have been forgotten, and particularly to benefit the youth of Okun land who have lost touch with the arts and culture of Okun people. She also said she aimed to correct the ills emerging among young people by explaining how good character and integrity are seen as the glory and essence of a person. The focus has been on traditional practices of 
asking for a girl's hand in marriage, marriage ceremonies and fashion, as well as indigenous words that have been lost by appropriation into Standard Yoruba. The programme also highlights the kinds of crafts and arts that Okun people were known for in the past, such as the weaving of clothes known as "Kitipa" and "Aso Oke" along with the tools used for that purpose, basket and mat weaving, and blacksmith work for making farm tools. At the onset, the programme was broadcast for 30 minutes, including time for listeners to call in. The live broadcast has however ended due to production costs. Like Dr Arokoyo, she now records and sends the episodes to Mr Ejibunu to air on radio.

When asked about the source of her knowledge for the programme she said that she gains her insight from reading Okun-Yoruba: Proverbs, Idioms, Wise Sayings and Some Aspects of Culture (Samuel, 2013) and by finding out information from many elderly people in and around Kabba town. Ms Ajayi is also an Owé indigene.

Idi Aro

The programme "Idi Aro", loosely translating as "At the Fireplace", is a programme about the food, drinks, spices and snacks of the Okun people. The initiator, Oluwakemi Kolawole, is a graduate of Geography and Environmental Management. She hails from Aiyetoro Gbedde, the İyàgbà group of Okun people. In the interview with her on 29 July 2017 , she said her motivation for the programme emanates from her passion for Okun indigenous condiments, drinks and culinary skills. Her aim is to share the knowledge of how to prepare the food and drinks and how to use condiments, especially for the benefit of Okun people in the diaspora who might have forgotten such culinary skills. In addition to writing the episodes, she contacted one of the local musical artists of Okun land to create a musical jingle for the programme. According to her, she created, recorded and sent three episodes to Mr Ejibunu but only one on how to make the indigenous soup Obe Akuku has been aired. She was unable to listen to the broadcast due to internet access problems. In addition to culinary skills, she hopes in future to create episodes on the traditional culture and practice of farming. When asked about the challenges she encountered, she mentioned that internet access was a problem along with the need for appropriate cell phone apps to do the recording. She advised that the radio needs to be physically established in order to attract a wider audience at grassroots level in Okun land, due to limited mobile coverage and internet access.

\section{Listeners' perspectives}

Three regular listeners to Okun Radio were interviewed on 29 and 30 July 2017. 
radio from the United Kingdom. The interviews were conducted on WhatsApp and Facebook Messenger.

According to Korede Emmanuel, the programmes are "entertaining and informative". When asked if he thinks the radio serves the purpose of connecting Okun people all over the world, he responded in the affirmative by alluding to the fact that the songs reflect the identity of Okun people from Ile Ife, the cradle of the Yoruba people. When asked whether the programmes and the use of Okun dialects help to preserve indigenous Okun languages and culture, he said he appreciated the promotion of the culture and heritage of Okun people and that "it can be an avenue for children who were not born in Okun land to know more about our cultural heritage". He did however point out that the awareness of Okun Radio is still low because few people in Okun land are used to online radio. He noted the lack of a physical location and its non-availability on local radio. He did however identify the online nature of the radio as also a source of strength as it could be "accessible to anyone, anywhere in the world" and "a tool for making the voice of Okun nation to be heard, any day anytime". He advised the founder to "avoid partisan politics" and to "uphold the ethics of journalism".

Mr Tunde Olugbami, an indigene of Ekirin Adde in the İjùmú local government, is very passionate about Okun Radio. He responded enthusiastically to the questions. He said he listens to the radio every day, has been a guest on the weekend programme and has also met Mr Ejibunu, the founder. He shared his awareness of many Okun indigenes who listen in from Australia, the United Kingdom, Germany, Austria, Nigeria, the United States of America, Canada and South Africa. He narrated how people in the diaspora from his hometown of Ekinrin Adde live-streamed an interview granted by their King and how "several hundred of people wrote about listening to it" either through email or on social media. Mr Olugbami describes the radio as "a good forum for our people" as most of the weekend programmes promote Okun music, the Okun nation and social cohesion among the towns and villages that make up Okun land. In his own words, "the radio provides the opportunity for Okun people in the diaspora to keep in touch with home". He declared that "a lot of people in the diaspora are enjoying the topical issues relating to development of Okun land which are discussed from time to time and to which listeners can call in to contribute or ask questions". He cited the current agitation for an upgrade of the Federal College of Agriculture in Kabba to a university and described how, as a guest on the radio, he was able to connect through WhatsApp with people worldwide and how afterwards he got five calls from friends in the diaspora and several more WhatsApp messages from listeners. All those who contacted him stressed the need for Okun people to be united in pursuing the common goal of having a university. Mr Olugbami mentioned that some of the issues discussed sometimes go beyond Okun land to Kogi State and how the Okun people have been marginalised, in spite of being some of the most educated people in the state.

He also mentioned how the radio can act as a catalyst to help Okun people overcome the differences and boundary problems which have often inhibited their progress at state and national levels of government. According to him, 

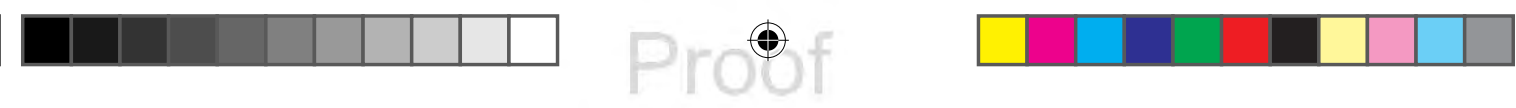

\section{0}

\section{Josephine Olufunmilayo Alexander}

embracing togetherness as one people, rather than seeing one another separately as belonging to Kabba, İyàgbà, İjùmú or Bùnú, will help to develop Okun land politically and allow them to forge common ground and strengthen their hand in the local and national legislatures. It is his opinion that identifying as one will embolden Okun elites to seek political positions. His assessment resonates with the content of the songs we analysed earlier on, further lending credence to the fact that the radio promotes unity and social cohesion among Okun people.

Mr Kenny Osisanya is from Ijebu-Ode in Ogun State of Nigeria but lives in the United Kingdom. He was interviewed on 30 July 2017. His only affiliation with Okun people is the fact that he is of Yoruba ethnic descent. His dialect of Yoruba is Ijebu and not Okun but the dialects are mutually intelligible to some extent. I saw his request on Okun Radio Facebook page asking for his son to be wished a happy birthday on the radio. I contacted him by email and subsequently connected with him on Facebook. When he informed me he is not from Okun land, I asked him why he is interested in a radio station that used Okun dialects and is specifically for Okun people. He responded by narrating how he wanted terribly to connect with home and how, when he searched the internet for any clue, he found Okun Radio and fell in love with it because he could identify with the Okun dialects even though he described it as "funny". He said listening to the radio brings back memories of home and living in Nigeria. In addition, he likes the radio because it promotes culture and tradition. He requested contact details for Mr Ejibunu, the founder of Okun Radio, because he is interested in starting a similar online station for his own dialect.

\section{Findings}

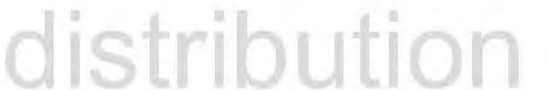

In this section, we explore Okun Radio Online by focusing primarily on the radio programmes and the interviews conducted with the initiators and presenters of programmes on the radio as well as interviews with three regular listeners to the radio. The overarching question is whether the radio has the potential for promoting Okun dialects and the traditional and cultural heritage of Okun people. Two specific questions are addressed:

1 How are Okun dialects maintained on Okun Radio?

2 How do the programmes on Okun Radio promote the traditional and cultural heritage of Okun people at home and in the diaspora?

The potential of the radio to promote Okun dialects and the traditional and cultural heritage of Okun people is made possible through the shared ancestry of Okun people as well as their primordial bonds to affirm their identity and promote their ethical interest. The will to preserve their language and cultural heritage from gradual attrition and endangerment is spearheaded by the vision of Mr Ejibunu, who, like others whose languages are marginalised, seized the new opportunities made possible by the Web 2.0 revolution to socially mobilise his ethnic group. The analysis and discussion of the content of the programmes that 
are aired on the radio provide answers to the two specific questions that inform this study.

\section{How are Okun dialects maintained on Okun Radio?}

More than 90 per cent of the programmes aired on the radio are in Okun dialects. This is particularly so with the music and other programmes like "Owé on Radio" and "Ufe Owé", the content of which is directly aimed at language documentation, preservation and revitalisation and, by extension, maintenance. Both programmes contribute to the learning and relearning of the Owé language and other Okun dialects. The symbiotic relationship between language and culture also means that Okun dialects are indirectly maintained as the dialects are the channels through which Okun cultural heritage is expressed in other programmes like "Iye Gha Ghon", "Ojomijo" and "Idi Aro".

The programmes broadcast on the radio primarily target Okun people in the diaspora who have very limited exposure to the use of their dialects and whose children may or may not have acquired them. Connecting Okun people all over the world with the radio programmes potentially increases their intergenerational transmission, especially with the active campaign on the radio for Okun people to value and use their languages. Research in language maintenance has emphasised the important role that attitudes of the speakers of minority languages play (Ignace 1998; Bradley 2002: 1; Hornberger 2004; Crystal 2011: 128; Mooko 2017: 123).

The visibility of Okun Radio programmes on social networks further enhances the prospect of maintaining Okun dialects, making it known beyond Okun land and Nigeria and extending their domains of usage from mere languages of interaction among Okun ethnic groups to languages that can be accessed online and used as the basis for research work, as is the case in this chapter. Okun Radio is accessible mainly from www.okunradio.com or www. okunradio.online and via tunein.com, plus.google.com and linkedin.com. It works well with Internet Explorer, Chrome, Safari and Firefox, and on mobile phones. The founder has also made considerable efforts to make Okun Radio programmes available on several social media sites, such as Facebook, Twitter and Instagram. For example, I accessed two past episodes of interviews on the radio on YouTube (www.youtube.com), and some past interviews are also accessible via SoundCloud. The visibility of Okun dialects on these social network sites also increases the desirability to develop their orthography and commit them to writing as they are predominantly oral languages.

More importantly, the presence of Okun dialects online has created relevant spaces for their usage. For example, the dialects are used to create political awareness, to discuss political and economic issues, to promote social cohesion, to advance community development and to advocate for positive attitudes towards using them, rather than shifting to other dominant languages. By using the dialects in more serious domains of life as above, they are being rescued from folklorisation and elevated to public domains (Fishman 1991: 91). 


\section{How do the programmes on Okun Radio promote the traditional and cultural heritage of Okun people at home and in the diaspora?}

The cultural and traditional heritages of Okun people are promoted directly in these programmes: "Ijomijo", "Iye Gha Ghon" and "Idi Aro", and indirectly by "Ufe Owé" and "Owé on Radio". The radio also airs cultural events, such as Ogidi Day, Kabba Day and Iyamoye Day. In addition, artists often incorporate aspects of culture and traditions in their songs, including proverbs and folklore tales. They also adopt a particular genre of Okun music and the associated musical instruments. Indigenous songs that affirm Okun tribal identity and nearly-forgotten traditional songs connected to ceremonial events and festivals are also aired, covering marriage, death and the new yam festival. Traditional percussion associated with Okun oral performances is common, as well as ululation and the formulaic invocation "Okun agbe gha" as a means of appreciating good performances.

Discussions on the need to preserve Okun dialects and oral traditions and culture are constantly promoted by guests who come to speak or be interviewed. As a musician and guest, for example, Mr Gboyega Ipinmoroti touched on aspects of culture and traditions that are going into extinction and implored listeners to make a concerted effort to preserve such traditions. He cited the use of indigenous names, transmission of Okun dialects to younger generations, the use of songs for character development, the social and political structure of Okun people before colonisation and the revitalisation of norms that promote social cohesion and good neighbourliness as aspects of dying culture that need to be revived. He also stressed the need to preserve traditional cults that were demonised as satanic by Christians. He advocated that cultural traditions should be documented and translated into English for posterity.

The concerted effort to promote the cultural heritage of Okun people is also demonstrated by the voluntary spirit with which Mr Ejibunu, Mr Oke, Dr Arokoyo, Ms Ajayi, Hajia Rakiya Yusuf and Ms Kolawole shared their wealth of knowledge on Okun dialects and cultural traditions with their kin in the diaspora, making it possible for them to remember what they have forgotten and encouraging them to value their languages and cultural identity. Mr Osisanya, one of the listeners interviewed, attested to how the radio provides an impetus for promoting cultural heritage, especially for those abroad.

The analysis and discussion of data also reveal that the radio has promoted social cohesion and community development among Okun people. In addition, the interviews on the radio have generated a lot of political and economic awareness, while the songs have advocated oneness, unity, forgiveness and reconciliation. Mr Olugbami also attests to how the radio "provides the opportunity for Okun people in the diaspora to keep in touch with home", thus fulfilling the founder's vison of using the radio as the platform for connecting Okun people all over the world and providing them a voice as an ethnic minority whose languages and culture are marginalised within the multilingual and multicultural milieu of Nigeria. 


\section{Conclusion}

In exploring whether Okun Radio Online is an impetus for maintaining the dialects and cultural heritage of Okun-Yoruba people, we have considered how minority ethnic groups and their languages are marginalised and dominated by other dominant languages within a multilingual society. We have also established the connection between language and ethnicity and the correlation between ethnic minority and minority languages. The data have been analysed through the lens of primordial ethnicity and Paulston's social mobilisation theory of language maintenance. The study has shown that ethnic minorities such as Okun people can tap into their ethnic affinity and the opportunities provided by the new technologies and social media to find the will to curb the gradual attrition of their languages and, by implication, their cultural heritage. This further demonstrates the role that social media and new technologies play in language preservation and maintenance, as attested to in the literature review.

The findings of the study accentuate the long-standing knowledge in sociolinguistics that the key factor in language maintenance is the attitude of the people whose languages are endangered. The Okun people are seen to be making a concerted effort to promote the preservation of their languages by actively participating in the programmes aired on Okun Radio Online in the absence of any government intervention to preserve their languages. As an ethnic group, they have made an effort to strategically promote the survival of their languages by rallying round the vision of one of their own who set up an internet radio service for the purpose of maintaining their marginalised languages and promoting their cultural heritage. It is noted that, while this effort has produced some results, access to the internet is a challenge, especially among Okun people in Nigeria who have no access or limited access to the internet and who can therefore not participate at all or fully in the radio programmes. It is also observed that not all Okun people in the diaspora are aware of the radio, even though it is visible on social media. The operation of the radio is also handicapped by financial constraints as it is based on voluntary efforts of a few people. Mr Ejibunu lamented the financial situation in the interview, as earlier stated, in the following words: "Initiating and starting Okun Radio Online has been a very rough, tough and lonely journey." He further described how he struggled financially to keep the website operating, stating that few people had wanted to do anything for free and that he only got support from one member of the Okun community.

The findings of this study also confirm some of the roles and functions that Batibo (2005: 32-37) ascribes to minority African languages such as Okun dialects. These roles and functions include cultural transmission, identity, socialisation, solidarity and cohesion, social relations and a vehicle for thought and intelligence.

A good development in the future would be to establish a physical radio station in Okun land in Nigeria where more people living at home can participate and further connect with those in the diaspora for the advancement of their languages and cultural transmission. 


\section{Josephine Olufunmilayo Alexander}

\section{Notes}

1 See Krauss (1992) for the evidence supporting his claim.

2 Other dialects of Yoruba apart from the Okun dialects are: Ekiti, Ijebu, Ọwọrọ, Ijesha, Akoko, Ikale, Oyo, Egba, Awori, Igbomina, Owo, Idanre, Egbado, Ilaje, Ketu, Ikale, Mokole and Lucumi.

3 Okun people, on 18 May 2017, re-established and asserted their origin to Ile-Ife by sending their representatives to pay homage to the Ooni of Ile Ife, Oba Adeyeye Enitan Ogunwusi. Ojaja II, for the development of the Okun cultural heritage (E-Reporter 2017).

4 Prior to leaving Nigeria for the United States, Mr Ejibunu had been a broadcaster in Abeokuta, Ogun State, Nigeria. He thinks of Okun Radio as his own way of giving back to his community. During the interview with him, he revealed that his idea for online radio was inspired by popular Nigerian broadcaster Yinka Aiyefele, who operated a radio online for seven years before establishing a physical station in Ibadan, south west Nigeria.

\section{References}

Primary sources

Interview with Mr Lanre Ejibunu on 20 May 2017

Interview with Hajia Rakiya Yusuf on 17 June 2017

Interview with Dr Bolanle Elisabeth Arokoyo on 13 July 2017

Interview with Mr Simon Oke on 15 July 2017

Interview with Ms Esther Folashade Ajayi on 29 July 2017

Interview with Ms Oluwakemi Kolawole on 29 July 2017

Interview with Mr Korede Emmanuel on 29 July 2017

Interview with Mr Tunde Olugbami on 29 July 2017

Interview with Kenny Osisanya on 30 July 2017

\section{Secondary sources}

Alia, V. (2010) The New Media Nation: Indigenous Peoples And Global Communications. New York: Berghahn Books.

Al-Saleem, B.I.T. (2011) Language and identity in social networking sites. International Journal of Humanities and Social Science 1(19), 197-202.

Androutsopoulos, J. (2006) Multilingualism, diaspora, and the internet: Codes and identities on German-based diaspora websites. Journal of Sociolinguistics 10, 419-438.

Androutsopoulos, J. (2014) Mediatization and sociolinguistic change: Key concepts, research traditions, open Issues. In J. Androutsopoulos (ed.) Mediatization and Sociolinguistic Change, 3-48. Berlin: de Gruyter.

Arokoyo, B.E. (2013) Owé Linguistics. Ilorin, Nigeria: Chridamel Publishing House.

Arokoyo, B.E. (2017) Owé Bilingual Dictionary. Oregon, USA: Living Tongues Institute for Endangered Languages.

Batibo, H.M. (2005) Language Decline and Death in Africa: Causes, Consequences and Challenges. Clevedon: Multilingual Matters Ltd.

Bayar, M. (2009) Reconsidering primordialism: An alternative approach to the study of ethnicity. Ethnic and Racial Studies 32(9), 1639-1657.

Bennett, J.W. (1975a) A guide to the collection. In J. Bennett (ed.) The New Ethnicity: Perspectives from Ethnology, 4-9. St. Paul: West Publishing. 
Bennett, J.W. (1975b) The New Ethnicity: Perspectives from Ethnology. St. Paul: West Publishing. St. Paul: West Publishing.

Bradley, D. (2002) Language attitudes: The key factor in language maintenance. In D. Bradley and M. Bradley (eds) Language Endangerment and Language Maintenance. London: RoutledgeCurzon.

Bradley, D. and Bradley, M. (eds) (2002) Language Endangerment and Language Maintenance. London: RoutledgeCurzon.

Browne, D.R. (2005) Ethnic Minorities, Electronic Media and the Public Sphere: A Comparative Approach. Euricom Monographs. Cresskill, NJ: Hampton Press.

Buszard-Welcher, L. (2001) Can the web help save my language? In L. Hinton and K. Hale (eds) The Green Book of Language Revitalization in Practice: Towards a Sustainable World, 331-348. San Diego: Academic Press.

Campbell, B. and Huck, J. (2013) Social media as a tool for linguistic maintenance and preservation among the Mapuche. Proceedings of the 2013 LAGO Graduate Student Conference Decolonizing the Americas 17.

Coupland, N. (2014) Sociolinguistic change, vernacularization and broadcast British media. In J. Androutsopoulos (ed.) Mediatization and Sociolinguistic Change, 67-96. Berlin: de Gruyter.

Crystal, D. (2000) Language Death. Cambridge: Cambridge University Press.

Crystal, D. (2011) Dying languages. In D. Crystal (ed.) A Little Book of Language. New Haven: Yale University Press.

Cunliffe, D. and Harries, R. (2005) Promoting minority-language use in a bilingual online community. New Review of Hypermedia and Multimedia 11(2), 157-179.

Deuber, D. and Hinrichs, L. (2007) Dynamics of orthographic standardization in Jamaican Creole and Nigerian Pidgin. World Englishes 26, 22-47.

Eisenlohr, P. (2004) Language revitalization and new technologies: Cultures of electronic mediation and the refiguring of communities. Annual Review of Anthropology 33, $21-45$.

Elazar, D. and Friedman, M. (1976) Moving Up: Ethnic Succession in America. New York: Institute on Pluralism and Group Identity of the American Jewish Committee.

E-Reporter (2017). Kogi Yoruba (Okun) strengthens relationship with Ile Ife. Available at https://ereporternews.com/2017/05/18/yeye-oge-of-okun-land-strengthens-therelationship-between-okun-and-ile-ife/. Accessed 16 July 2018.

Fase, W., Jaspaert, K. and Kroon, S. (eds) (1992) Maintenance and Loss of Minority Languages. Amsterdam: John Benjamins Publishing Company.

Fishman, J.A. (1991) Reversing Language Shift: Theoretical and Empirical Foundations of Assistance to Threatened Languages. Clevedon: Multilingual Matters.

Fishman, J.A. (2001) From theory to practice (and vice versa): Review, reconsideration and reiteration. In J.A. Fishman (ed.) Can Threatened Languages be Saved? Reversing Language Shift, Revisited: A 21st Century Perspective, 451-483. Clevedon: Multilingual Matters.

Glazer, N. and Moynihan, D.P. (1975) Introduction. In N. Glazer and D.P. Moynihan (eds) Ethnicity: Theory and Experience, 1-26. Cambridge: Cambridge University Press.

Grenoble, L.A. (2006) Saving Languages: An Introduction to Language Revitalization. Cambridge: Cambridge University Press.

Grenoble, L.A. and Whaley, L.J. (eds) (1998a) Endangered Languages: Current Issues and Future Prospects. Cambridge: Cambridge University Press. 


\section{Josephine Olufunmilayo Alexander}

Grenoble, L.A. and Whaley, L.J. (1998b) Toward a typology of language endangerment. In L.A. Grenoble and L.J. Whaley (eds) Endangered Languages: Language Loss and Community Response, 22-54. Cambridge: Cambridge University Press.

Harrison, R. and Thomas, M. (2009) Identity in online communities: Social networking sites and language learning. International Journal of Emerging Technologies and Society 7(2), 109-124.

Hepp, A. (2014) Mediatization: A panorama of media and communication research. In J. Androutsopoulos (ed.) Mediatization and Sociolinguistic Change, 49-66. Berlin: de Gruyter.

Hinton, L and Hale, K. (2001) The Green Book of Language Revitalization in Practice. San Diego: Academic Press.

Hornberger, N. (2004) Indigenous language revitalization, biliteracy, and student voice: Instance from Quechua, Guarani, and Maori bilingual education. Plenary talk presented at the Dialogue on Language Diversity, Sustainability and Peace, Linguapax Institute, Barcelona, 21 May.

Horowitz, D. (2002) The Deadly Ethnic Riot. Berkeley: University of California Press.

Ignace, M. (1998) Handbook for Aboriginal Language Programme Planning in British Columbia. Available at www.fnesc.ca/publications/pdf/language.pdf. Accessed 16 July 2018.

Jones, R.J., Cunliffe, D. and Honeycutt, Z.R. (2013) Twitter and the Welsh language. Journal of Multilingual and Multicultural Development 34(7), 653-671.

Joubert, A. and Biernacka, K. (2015) Cultural heritage and new technologies: The role of technology in preserving, restoring and disseminating cultural knowledge. Southern Africa Journal for Folklore Studies 25 (Supplement 1), S21-S33.

Karim, H.K. (ed.) (2003) The Media of Diaspora. London: Routledge.

Kimmons, R. (2014) Social networking sites, literacy, and the authentic identity problem. TechTrends 58(2), 93-98.

Krauss, M. (1992) The world's languages in crisis. Language 68(1), 4-10.

Krotz, F. (2003) Metaprozesse sozialen und kulturellen Wandels und die Medien. Medien Journal 27(1), 7-19.

Krotz, F. (2007) Mediatisierung. Fallstudien zum Wandel von Kommunikation. Wiesbaden: VS.

Krotz, F. (2009). Mediatization: A concept with which to grasp media and societal change. In K. Lundby (ed.) Mediatization: Concept, Changes, Consequences, 19-38. New York: Peter Lang.

Ladefoged, P. (1992) Another view of endangered languages. Language 68(4), 809-811.

Leggio, D.V. (2011) The Romani internet: Language codification and identity formation. Paper presented at the Annual Meeting of the Gypsy Lore Society, Graz, Austria, 1-3 September. Available at http:/romani.humanities.manchester.ac.uk/virtuallibrary/ publications.html. Accessed 19 February 2017.

Matsumura, K. (ed.) (1998) Studies in Endangered Languages. Papers from the International Symposium on Endangered Languages. Tokyo, 18-20 November 1995. Tokyo: Hituzi Syobo.

McKay, J. (1992) An exploratory synthesis of primordial and mobilization approaches to ethnic phenomena. Ethnic and Racial Studies 5, 395-420.

Mensching, G. (2000) The internet as a rescue tool of endangered languages: Sardinian. Paper presented at the conference Multimedia and Minority Languages in San Sebastian, 8-9 November. Available at www.gaia.es/multilinguae/pdf/Guido.PDF. Accessed 18 February 2018. 
Mooko, T. (2017) Counteracting the threat of language death: The case of minority languages in Botswana. Journal of Multilingual and Multicultural Development 27(2), 109-125.

Oiarzabal, P.J. (2012). Diaspora Basques and online social networks: An analysis of users of Basque institutional diaspora groups on Facebook. Journal of Ethnic and Migration Studies 38, 1469-1485.

Oke, S. (2016) Owé T'Ano: Oke Meta Owé Cultural Heritage. Kabba: God First Integrated Press.

Ola-Busari, J.O. (2015) Restoring Owé traditional knowledge: A technological journey of reclamation. Southern Africa Journal for Folklore Studies 25 (Supplement 1), S114S127.

OmoOkun (2014) An interdisciplinary journal of Okun-Yoruba of Kogi State Nigeria, 1(1).

Ouakrime, M. (2001)Promoting the maintenance of endangered languages through the internet: The case of Tamazight. In C. Moseley, N. Ostler and H. Ouzzate (eds) Endangered Languages and the Media: Proceedings of the Fifth FEL Conference, Agadir, Morocco, 20-23 September, 61-67. Bath: FEL.

Paulston, C.B. (1994) Linguistic Minorities in Multilingual Settings: Implications for Language Policies. Amsterdam: John Benjamins Publishing Company.

Paulston, R.G. (1977). Separate education as an ethnic survival strategy: The Finladssvenska case. Anthropology and Education Quarterly 8(3), 181-188.

Rajah-Carrim, A. (2009) Use and standardization of Mauritian Creole in electronically Mediated Communication. Journal of Computer-Mediated Communication 14, 484-508.

Reershemius, G. (2010) Niederdeutsch im Internet. Möglichkeiten und Grenzen computervermittelter Kommunikation für den Spracherhalt. Zeitschrift für Dialektologie und Linguistik 77, 183-206.

Reershemius, G. (2016) Language shift revisited: Linguistic repertoires of Jews in Low German-speaking Germany in the early twentieth century. Insights from the LCAAJ Archive. Journal of Germanic Linguistics, 7 December 2016. Available at www.cam bridge.org/core/journals/journal-of-germanic-linguistics. Accessed 11 February 2018.

Reershemius, G. (2017) Autochthonous heritage languages and social media: Writing and bilingual practices in Low German on Facebook. Journal of Multilingual and Multicultural Development 38(1), 35-49.

Roth, L. (2000) Bypassing of borders and building of bridges. International Communication Gazette 62(3-4), 251-269.

Sallabank, J. (2010) The role of social networks in endangered language maintenance and revitalization: The case of Guernesiais in the Channel Islands. Anthropological Linguistics 52(2), 184-205.

Samuel, J.O. (2013) Okun-Yoruba: Proverbs, Idioms, Wise Sayings and Some Aspects of Culture. Lagos, Nigeria: Father's Heart Publishers.

Seargeant, P., Tagg, C. and Ngampramuan, W. (2012) Language choice and addressivity: Strategies in Thai English social network interactions. Journal of Sociolinguistics 16, $510-531$.

Sharma, B.K. (2012) Beyond social networking: Performing global Englishes in Facebook by college youth in Nepal. Journal of Sociolinguistics 16, 483-509.

Siziba, L.P and Wood, F. (2015) Fighting over Ndebele identity through online forums: Quarrels of the vanquished? Southern Africa Journal for Folklore Studies 25 (Supplement 1), S34-S45. 


\section{Josephine Olufunmilayo Alexander}

Skågeby, J. (2011) Online ethnographic methods: Towards a qualitative understanding of virtual community practices. In B.K. Daniel (ed.) Handbook of Research on Methods and Techniques for Studying Virtual Communities, 410-428. New York: Information Science Reference.

Stern, A.J. (2017) How Facebook can revitalise local languages: Lessons from Bali. Journal of Multilingual and Multicultural Development 38(9), 788-796.

Tiam-Tong, C.S. (1996) The Role of Communication in Preserving Cultural Identity in Northern Thailand. Chiang Mai, Thailand: Department of Mass Communication, Chiang Mai University.

Uribe-Jongbloed, E. (2016) Issues of identity in minority language media production in Colombia and Wales. Journal of Multilingual and Multicultural Development 37(60), 615-627.

Warschauer, M. (1998) Technology and indigenous language revitalization: Analyzing the experience of Hawai'i. Canadian Modern Language Review 55(1), 140-161.

Warschauer, M. (2000) Language, identity, and the Internet. In B. Kolko, L. Nakamura and G. Rodman (eds) Race in Cyberspace, 151-170. New York: Routledge.

Warschauer, M., El Said, G. and Zohry, A.G. (2002) Language choice online: Globalization and identity in Egypt. Journal of Computer-Mediated Communication (JCMC) 7(4).

Wolff, S. (2006) Ethnic Conflict: A Global Perspective. Oxford: Oxford University Press.

Yang, P.Q. (2000) From Ethnic Studies: Issues and Approaches. New York: State University of New York Press.

Zhuravleva, A., de Bot, K. and Hilton N.H. (2016) Using social media to measure language use. Journal of Multilingual and Multicultural Development 37(6), 601-614. 